\title{
Watanabe Kaigyoku and Buddhist Responses to the 'Labour Question' in Early-Twentieth Century Japan
}

\author{
CAMERON PENWELL
}

Library of Congress

Keywords: Engaged Buddhism, Japanese Labour Problem, Buddhist Social Reform, Watanabe Kaigyoku

DOI: https://dx.doi.org/10.15239/hijbs.02.02.05

Abstract: Watanabe Kaigyoku 渡辺海旭 (1872-1933) was a Jōdoshū priest and scholar who contributed significantly to the fields of Buddhist education and social work in Japan, particularly following his return home in 1910 after a decade of study in Germany. Seeking to meld Buddhist ethics with modern methods of social work, Watanabe established the Jōdoshū Workers' Mutual Aid Society in 1911. An exploration of his writings and the historical context behind the creation of this organization reveals that Watanabe did not envision a radical position for Buddhists on the issue of the 'labour question'; rather, he imagined Buddhism as a harmonizing influence that could help avoid the pitfalls of unrestrained capitalism, on the one hand, and revolutionary socialism, on the other. The theoretical and practical approaches to social work of Japanese Buddhists like Watanabe should be viewed as early examples of what is now called 'engaged Buddhism', a category whose history has largely been restricted to the post-World War II era. 
Tn April 2017, two Shin Buddhist priests in Japan successfully collected compensation for unpaid overtime wages from the Shinshū Ōtani-ha religious organization. The two priests, who joined and received assistance from a general union, sought compensation for overtime labour performed over the course of a four-year limited-term contract at a national training centre for Shinshū Ōtani-ha. The priests frequently put in fifteen-hour days over the course of the contract, sometimes accruing as many as one hundred hours of overtime labour a month, for which they were not properly compensated. ${ }^{1}$

At first glance the case appears as something of a curiosity, blending two realms of activity, Buddhism and labour relations, not typically imagined alongside each other. The details, however, speak to a systemic problem in contemporary Japan of an overworked labour force. While this case was being settled, politicians and business leaders continued to debate suitable policy responses to a high-profile 2015 suicide, officially recognized as a 'death by overwork' (karōshi 過労死), by a young female employee at the country's largest advertising firm. Moreover, at a time when contingent labour makes up a rapidly growing portion of the Japanese workforce, workers increasingly find themselves in a vulnerable position when pressed with unfair or illegal demands from management. Against this backdrop, the above case prompted discussions about the nature and boundaries of clergy labour. Where does 'labour' end and 'ministry' or 'ascetic training' begin? A recent editorial in Chügai Nippō, the largest newspaper in Japan devoted to coverage of religious affairs, argues that Buddhist religious orders and their temples must set an example for the creation of a humane work place environment that values human health and happiness above other concerns. ${ }^{2}$ As Buddhists in Japan endeavour to overcome the real or imagined confines of 'funerary Buddhism' and stake out new terms for social engagement, skilfully devising a dharma-inspired approach to address the dehumanizing aspects of the country's labour conditions-and the psychological and physical suffering those conditions produce-

\footnotetext{
1 Miyakawa, 'Shinshū Ōtani-ha', 8.

2 'Rōdō to hōshi no aida' 労働と奉仕の間.
} 
stands alongside contemporary efforts in suicide prevention and disaster relief as a notable area in which Buddhists can meaningfully contribute to society.

Such an effort would not, however, be the first time Japanese Buddhists attempted to address labour conditions and problems facing workers. In the early-twentieth century, the stakes of the so-called 'labour question' carried a great sense of urgency: what should be done to address the increasingly contentious relationship and socio-economic divide between employees and employers? Buddhists concerned about these problems turned their attention to the tumultuous state of labour, poverty, and unemployment that faced Japanese workers in the early twentieth century. Their response to the labour issue was a driving factor in the emergence of modern Buddhist social work, as they sought to address both the economic inequality produced by industrial capitalism, as well as the real or perceived threat to the social order posed by the growth of organized labour and socialism.

After the end of the Russo-Japanese War in 1905, a string of violent protests broke out, reflecting public anger over Japan's meagre extractions from the war settlement as well as economic hardship driven by high war-time taxes. Over the next few years, related displays of public anger followed: further protests in Tokyo over streetcar fare increases, a worker-led riot at Japan's largest mine in 1907, and the quashing of a socialist political rally in 1908. Fear spread among business and political elites that global socialism might infect the growing labour movement in Japan and lead to destabilizing class conflict. In 1908, the Ministry of Home Affairs held the first of what would become a regular series of Reformatory and Relief Work Seminars. The seminars were one of the Home Ministry's long-running efforts to popularize and promote private charity and relief work among wealthy philanthropists, middle-class professionals, and do-gooders of various stripes. They were particularly interested in the potential for clergy, whether Buddhist, Christian, or Shinto, to implement 'spiritual poverty prevention' (seishin bōbin 精神防貧), which essentially amounted to using religion to instill and reinforce values of long-suffering thrift and self-reliance as an anti-poverty strategy. By addressing these social problems incrementally, through private efforts, Home Ministry bureaucrats hoped to forestall social 
unrest and political revolution. Amid these developments, growing numbers of Buddhist clergy turned to social work as a method for implementing compassion, relieving suffering, and ameliorating some of the social disparities that gave rise to the labour question.

One of the earliest advocates for Buddhist social work, Watanabe Kaigyoku 渡辺海旭 (1872-1933), placed the labour question front and centre in his programme of Buddhist-inspired social activism. ${ }^{3}$ While some critics might dismiss efforts to mollify hardships faced by the working class as a reactionary attempt to preserve the status quo, the case of Buddhists like Watanabe is not so simple. He and his like-minded contemporaries occupied a political middle-ground that can be easy to lose sight of when viewing Japanese political and social history through binary categories like radical and conservative or modern and traditional. A careful look at his life reveals a more complex picture.

\section{Watanabe's early life and ten-year stay in Germany}

Born in the Asakusa district of Tokyo in 1872, Watanabe entered the priesthood at the age of thirteen at Genkaku-ji 源覚寺, a Jōdoshūaffiliated temple in Koishikawa, Tokyo. ${ }^{4}$ In 1895 he completed the comprehensive course of study at the Jōdoshū Main School (Jōdoshū honkō 浄土宗学本校), a forerunner of present-day Bukkyō University. Among his classmates were Mochizuki Shinkō 望月信 亭 (1869-1948) and Ogiwara Unrai 荻原雲来 (1869-1937), fellow Jōdoshū clergy who, like Watanabe, would go on to accomplished

3 The conventional reading for the combination of Chinese characters used to write 海旭 is 'Kaikyoku'. Many Buddhist sources, however, use the reading 'Kaigyoku', including the online edition of the Shinsan Jödoshū daijiten 新纂浄 土宗大辞典 [The New Jōdoshū Dictionary] (http://jodoshuzensho.jp/daijiten/). I have adopted this reading, based also on conversations with Jōdoshū scholars and clergy in Japan.

4 The biographical sketch here is drawn from Serikawa, Bukkyō, 41-44. This volume of Serikawa's collected works contains much of the material originally published in 1978 in the now out-of-print Serikawa, Watanabe Kaigyoku. 
careers as scholar-priests. Upon graduation he was assigned to teach at the Jōdoshū First School (Dai ichi kyōkō 第一教校) in Tokyo and also began writing for the Jōdo kyōhō 浄土教報, a biweekly journal that essentially served as the official organ of Jōdoshū. ${ }^{5}$ Watanabe's intellectual potential was evident to Jōdoshū leadership, who sent him to pursue further study in comparative religions in Kyoto in $1896 .{ }^{6}$ In 1898 , at age twenty-six, Watanabe assumed duties as head priest at Saikō-ji 西光寺, a Jōdoshū temple located in a working class area called Fukagawa, near the Sumida River on the east side of Tokyo. ${ }^{7}$ By the turn of twentieth century, Watanabe emerged as one of the leading young lights within Jōdoshū. Not only did he teach at the sect's main secondary school in Tokyo, he also served as chief writer and editor for Jödo kyōhō. In 1900, the sect's leadership selected Watanabe as one of its first priests to pursue graduate studies abroad, which culminated in his earning a doctorate in Buddhology during a ten-year sojourn as a student and researcher in Germany at Kaiser-Wilhelm-Universität (now Strasbourg University in France). ${ }^{8}$

Beyond his activities in academia and religious circles, Watanabe took an interest in the politics of the Social Democratic Party of Germany (SPD) and observed new operational forms of social work like the settlement house. These facilities, known in German as the Arbeiterheim ('worker's house') or Volksheim ('people's house'), adapted the settlement model from Toynbee Hall in London, in which middle-class volunteers served in settlement houses established in impoverished areas with the goal of providing various educational and social services. This model, which was also adopted by Jane Addams at Hull House in Chicago, would profoundly influence his vision for the Jōdoshū Workers' Mutual Aid Society. Watanabe also engaged in a variety of intellectual pursuits, participating in the

5 In the 1910s, the publication schedule was moved up to a weekly basis.

6 Serikawa, Bukkyō, 41.

7 The temple was located in Honjo ward, which was consolidated into present-day Sumida ward in 1947.

8 During the period in which it was under German rule (1872-1918), the university was known as Kaiser-Wilhelm-Universität. 
German Freethinkers League and taking part in discussions with student radicals from the Russian Empire who had fled to Germany following the Revolution of 1905.' Regarding his acquaintances who identified as anarchists, Watanabe wrote, 'As one who follows the Buddha's teachings on the Middle Way I've tried to turn them toward becoming more sensible socialists'. Other comments in letters and dispatches from Germany suggest that Watanabe was sympathetic to socialist causes, even if he did not support them unreservedly. ${ }^{10}$

Watanabe began writing for publication on a regular basis in the late 1890s, first at Jōdo kyōbō and shortly thereafter for Shin bukkyō, the journal of the Fellowship of New Buddhists (Shin bukkyō dōshikai 新 仏教同志会). ${ }^{11}$ While abroad, Watanabe sent several dispatches back to journals like Jódo kyōbō and Shin bukkyō that detailed experiences during his decade-long sojourn in Germany. These pieces, written something in the vein of a travelogue, betray a certain youthful frankness and offer a window onto Watanabe's personality and intellectual influences in a way that more formal essays published after his return to Japan in 1910 do not. Among the most interesting and revealing of these pieces is 'Meditations on the setting sun from the tower and miscellaneous impressions' (hereafter 'Meditations'), published in Jödo kyōō in 1901. ${ }^{12}$ Written during the first year of his stay in Germany,

\footnotetext{
9 Serikawa, Bukkyō, 55.

10 Watanabe, 'Kochū kenkon', 443.

11 Most of his published writings can be found in the two-volume edited collection, Kogetsu Zenshü, published by colleagues shortly after his death in 1933 and reprinted in 1977. More detailed exploration of Watanabe's personal life is complicated by the fact that most of his private writings seem to have been destroyed when Saikō-ji burned down amid the disastrous 1923 Kantō Earthquake.

12 Watanabe, 'Nissōkan rō zakkan'. The phrase 'Meditations on the setting sun', is a reference to the first of the sixteen meditations in the Sutra of the Meditation on the Buddha of Immeasurable Life (Skt. Amitāyurdhyāna Sütra C. 觀 無量壽經), in which viewing the sun setting in the West prompts one to reflect upon Amitabha Buddha's Pure Land of Bliss. See entries for '日想觀' and ‘觀無 量壽經' in the Digital Dictionary of Buddhism (www.buddhism-dict.net/ddb/) for further references.
} 
this essay offers a glimpse of his early impressions of German society. Much of what he observed and experienced would later influence his thinking about the role that Buddhism should take in Japan.

The 'Meditations' essay contains the early outlines of one of Watanabe's abiding intellectual concerns, which took formative shape in Germany, namely, the role of religion in modern society. Watanabe had begun to conceptualize religion's relationship with state and society primarily in terms of the ways in which religion functioned to harmonize society in the present while also holding the potential to serve as a spiritual wellspring of reform capable of perfecting state and society in the future. This view of religion as a stabilizing or harmonizing social force coalesced during his first year in Germany, as he observed the ways in which Protestant and Catholic churches and organizations played an active social role in Wilhelmine Germany. Much in the same way that early architects of social policy in Japan turned to the example of countries like Britain, and especially Germany, to foresee potential causes of, and solutions to, social problems that lurked on the horizon in the late-Meiji, so too did Watanabe closely observe religion-state and religion-society relations in Western Europe to serve as a guide for his own formulations of the path Buddhism should take in fulfilling its destiny as a 'social religion' for Japan in the twentieth century. ${ }^{13} \mathrm{He}$ observed that, in spite of frequent philosophical and scientific attacks on Christianity in German academia, the Christianity of both the state Protestant and Catholic churches maintained strong roots, which he believed reflected the indestructible power of religion. Scholars may question the value of religion, he noted, but the degree to which religious sentiment could motivate people to practical action-carrying for the needy, hungry, and sick-should offer enough proof that it was not without value. 'The basic factor behind the influence religion wields in society is quite simple', he remarked, 'and the lifeblood of Western Christianity can be found there'. ${ }^{14}$ In other words, religion's power (and the proof of that power) was to be found in its ability to inspire

13 See, for example, Pyle, 'The Advantages of Followership'.

14 Watanabe, 'Nissōkan rō zakkan', 413. 
practical action to relieve suffering and improve society. In emphasizing the practical contributions of Christian religion alongside the philosophical or scientific critique to which it was also subjected, Watanabe emphasized the empirical evidence for religion's utility over the theoretical aspect of criticism against it. ${ }^{15}$ Shortly prior to writing 'Meditations', he observed:

The reason why religion unites public sentiment and maintains moral leadership is not found in the impractical theories of 'essential nature and phenomenal expression', nor in the empty words of proselytizing. Likewise, it is not found in exquisitely decorated sanctuaries, nor has it ever had to do with the calculated expediency of secular concerns. It is only in practical acts that result from faith, only in charitable social work (jizenteki shakai jigyo 慈善的社会事業). ${ }^{16}$

Based on his observations of Germany and other countries in Europe, Watanabe devoted significant time to thinking about the social role and function of religion and its relationship to the nation-state. His interest in this problem was directly related to his concern for how Buddhists in Japan could make their religion's usefulness known in meaningful and practical ways. Watanabe later developed his ideas concerning Buddhist social work through a larger vision of Mahayana Buddhism as a social religion equipped with the spiritual and ethical values necessary for overcoming contemporary social and economic problems; it was, he would later argue, the religion of the future. ${ }^{17}$ His notion of what constituted a 'social religion' and of how a religion might become 'social' were informed by his attempts to make sense of the role that religion played in German society. In 'Meditations', Watanabe repeatedly commented on the

15 He phrased it as 'evidence over theories' (ron yori shōko 論より証拠). Watanabe, 'Meditations', 413.

16 Jödo kyōhō, no. 425, 1901. Quoted in Kikuchi, 'Watanabe Kaigyoku', 178. This quotation is also one of the earliest known instances of the neologism shakai jigyo 社会事業 being used as a translation for 'social work' in print.

17 Watanabe, 'Daijō Bukkyō no seishin'. 
effect he perceived religion had on harmonizing the rising conflict between rich and poor in Germany, as well as on the contributions that religion made to the development of society and for the benefit of the nation through charitable activities and social work.

In Europe, religion acts as a harmonizer between the rich and the poor. It is a friend of the poor. But as society progresses, a glaring gap grows between the two. The benefits of civilization accrue only to those with money. How lamentable is today's society; but it cannot be helped. Educating the lower strata of society-the poor and weak-extending charity, and giving them jobs: none of these can be accomplished unless the religious take the initiative. These kinds of noble-minded projects will not succeed unless they come from religious faith. ...Conjecturing about Japan's future based on the present, we [Buddhists] must pay greater attention to social work and charity work in order to contribute to [building a] nation with a society capable of developing in a sound and healthy way. This is the fundamental way that religion can gain respect from society and maintain its value. ...I may be speaking out of place here as a young priest, but I would like for our missionaries and teachers to take heed and, in one way or another, become leaders in addressing the problem of action, that is, action that benefits the nation. Does not Buddhism possess a foundation of exceptional social morality that is not found in other religions, based on such teachings as 'bringing benefit and joy to sentient beings' (riraku ujo 利楽有情) and 'the debt of gratitude to all sentient beings' (shujōon 衆生恩)? ${ }^{18}$

The ideas that Watanabe puts forward here must be viewed against the historical backdrop of contemporary events in Japan that were of deep concern in the Buddhist world, such as the implementation of the equal treaties and mixed residency in 1899, debates over 'officially recognized religion' (kōninkyō 公認教) in 1899 and 1900, and disagreement over the Religions Bill and its ultimate defeat in the Diet in 1900 and 1901. ${ }^{19}$ Disagreements over Buddhism's status as an

\footnotetext{
18 Watanabe, 'Nissōkan rō zakkan', 413.
} 
'officially recognized religion' and other issues featured prominently in the proposed Religions Bill that emerged prior to Watanabe's departure, and it is likely that Watanabe remained informed of the developments affecting Buddhism and religion in Japan more generally, such as the fate of the Religions Bill.

Watanabe admired the achievements of German science, industry, and commerce and stressed that a strong commitment to education-especially the high quality of universities — enabled these successes. He also praised the thrift of the German people, describing it as a defining national characteristic. Reflecting back on the situation of Buddhists in Japan, especially his own Jōdo sect, Watanabe asserted that Buddhists must begin placing a greater emphasis on education and move away from their religion's focus on building temples, performing ceremonies, and generally 'putting on airs' of tradition if they truly hoped to wield greater influence in society. $\mathrm{He}$ likewise condemned social outreach that was self-serving, lamenting that 'Missionary activity that is nothing more than lip service isn't worth a damn in today's society. Proselytizing that is all about raising money or is otherwise hypocritical is actually a blight on society'. ${ }^{20}$

By the time Watanabe left Germany to return to Japan in 1910, the basic intellectual framework of his approach to social work had coalesced. Over the ensuing decade, he outlined and elaborated this framework, drawing inspiration from German social policy and contemporary theories of social work but always conceptualizing and interpreting these through the prism of Mahayana Buddhist metaphysics and ethical thought. His approach to social work was also informed by practice, exemplified by his establishment of the Jōdoshū Workers Mutual Aid Society and the Buddhist Social Work Research Group, as well as the model of church-state relations and social programs of the Catholic and Protestant churches in Germany. The following section will examine in greater detail how these influences figure into Wata-

19 These debates concerned the question of whether the state should regulate religious organizations and, if so, how they should be regulated. For a cogent summary and analysis of these debates, see Thomas, 'Faking Liberties', 49-73.

20 Watanabe, 'Nissōkan rō zakkan', 414. 
nabe's conception of Buddhism as a social religion in the nation-state of Japan and the Buddhist principles that should guide Buddhist social work as a response to poverty and other forms of suffering.

\section{Watanabe's return to Japan and the Jōdoshū Workers' Mutual Aid Society}

After spending a decade abroad, Watanabe returned to Japan in 1910 and once again settled in Tokyo. He soon devoted himself to three closely related fields of activity that occupied his energies for the remainder of his life: religious service, scholarship and education, and social work. He returned to his earlier post as head priest at Saikō-ji, began teaching at Shūkyō University (now Taishō University), and resumed duties as chief editor of Jödo kyōhō. In 1911, he assumed the additional responsibility of serving as principal for Jōdoshū's Shiba Middle School. That same year, Watanabe decided to put his evolving ideas about social work into practice by launching what was to become the first Buddhist welfare project based on the settlement house model, the Jōdoshū Workers' Mutual Aid Society (Jōdoshū rōdō kyōsai kai 浄土宗労働共済会), not far from his home temple in Fukagawa. At the time of its establishment in 1911, when Japan lacked any kind of comprehensive social insurance system, the Jōdoshū Workers' Mutual Aid Society was a notable social welfare undertaking, focused on providing lodging and job-matching assistance to the urban underclass of eastern Tokyo. ${ }^{21}$ Watanabe's return to Japan and founding of the Mutual Aid Society according to his understanding of new forms of 'scientific' social work reflected an operational transition away from 'charity' toward 'social work', a move that aimed to identify and address deeper structural causes of poverty rather than simply responding to its symptoms. One year later, Watanabe established and began overseeing the Buddhist Social Work Research Group (Bukkyōto shakai jigyō kenkyūkai 仏教徒社

21 One notable antecedent, briefly mentioned below, is a free lodging house established by the Ōtani-ha temple Asakusa Hongan-ji in Tokyo. 
会事業研究会), which coordinated communication among some eighty-member organizations around the country and conducted studies aimed at improving social work methods. ${ }^{22}$

The Jōdoshū Workers' Mutual Aid Society constituted a response to a diverse set of issues facing Japanese society in 1910 and reflected the knowledge, experience, and personal concerns of Watanabe Kaigyoku. At the same time, while Watanabe was designated director, the launch of the project resulted from the cooperative work of several individuals in the Jōdoshū leadership, who treated it as a sectwide effort and sought to imbue it with wider symbolic value. The organization's charter statement, published in Jödo kyōbō in April 1911, clearly explained that its launch was meant to commemorate the seven-hundredth anniversary of the death of sect founder Hōnen and to reflect appreciation for the Meiji emperor's magnanimity:

In recognition of the seven-hundredth anniversary of the death of our sect's founder [Hōnen], the Meiji emperor has proclaimed his great virtue and bestowed the posthumous title of Meishō Daishi upon him. The favour of the emperor is truly as deep as the ocean and as high as the mountains. It is our sincere desire to respond, in whatever small way, to our vast debt of gratitude to the nation by assisting in time of emergency in those areas where the state is unable to provide. ...we shall pour our strength into establishing the Jōdoshū Workers' Mutual Aid Society and ...strive first and foremost to improve the conditions of daily life for individual workers. ${ }^{23}$

The more sudden, direct, and traumatic event that shaped the historical context of the Mutual Aid Society's formation was the Great Treason Incident of $1910 .{ }^{24}$ The incident, in which authorities

22 Nihon bukkyō shakai fukushi gakkai, Bukkyō shakai, 272-73.

23 'Jōdoshū rōdō kyōsai kai shuisho' 浄土宗労働共済会趣意書, first appearance in print was Jōdō kyōhō, no. 949, April 3, 1911, 6-7. More recently, it was reprinted in full in Masaharu and Yasuo, Nibon shakai, 223-24.

24 For a comprehensive account in English, see Gavin and Middleton, Japan and the High Treason Incident. 
uncovered an alleged socialist plot to assassinate the Meiji emperor, seemed to confirm the worst collective suspicions about social unrest and heterodox political ideologies. Anxieties created by the incident, which started in May 1910, lurked in the background of the Mutual Aid Society's formation, especially because three Buddhist clergy were among those arrested and sentenced to death on January 18, 1911, for suspected involvement in the failed assassination plot: Sōtō Zen priest and anarchist Uchiyama Gudō 内山愚童 (1874-1911); Shinshū Ōtani-ha priest Takagi Kenmyō 高木顕明 (1864-1914); and Rinzai Zen priest Mineo Setsudō 峯尾節堂 (1885-1919). Two others, Shingon priest Mōri Seian 毛利柴庵 (1871-1938) and Sōtō Zen priest Inoue Shūten 井上秀天 (1880-1945), were not indicted, but authorities searched their homes and placed them under surveillance. Authorities even detained Itō Shōshin 伊藤証信 (1876-1963), a Shinshū Ōtani-ha priest and founder of the 'selfless love' (muga ai 無我愛) movement, due to an essay that Itō wrote about the incident. Uchiyama was executed on January 24, 1911, while Takagi's and Mineo's sentences were commuted to life in prison. Takagi, who vocally opposed the Russo-Japanese War and worked doggedly to improve conditions for the burakumin outcaste group, took his own life just two years later while incarcerated at Akita Prison. ${ }^{25}$ Also sentenced to death was Sasaki Dōgen 佐々木道元 (1889-1916) who, while not a priest, was born to a Shinshū temple family in Kumamoto prefecture. Like Takagi and Mineo, his sentence was commuted to life in prison. ${ }^{26}$

The number of Buddhist individuals linked to the event, however directly or indirectly, caused alarm among temple leadership of all sects. Head temples quickly defrocked and denounced those priests who were convicted. A directive from Sōtō Zen leadership instructed priests and parishioners to 'exercise vigilance over both themselves and others ... In order to expiate this most serious crime in the sect's last one thousand years'. ${ }^{27}$ Rinzai Zen administrative head Toyoda

25 For further details on the life and career of Takagi, see Swanson, 'Takagi Kenmyo'. For a concise study of Uchiyama's life and translations of his major essays, see Rambelli, 'Zen Anarchism'.

26 Yoshida, Nibon kindai, 26-27. 
Dokutan (1840-1917) reasserted that the essence of the Rinzai sect was 'to protect the nation through the spread of Zen' and pledged to continue to promote loyalty to the emperor while also ensuring that adherents 'don't ignore the doctrine of karma or fall into the trap of believing in the heretical idea of "evil equality" that was being advocated by socialists and their ilk. ${ }^{28}$ Meanwhile, in light of Takagi's conviction, two Shinshū Ōtani-ha administrators, Ōtani Eiryō 大谷 瑩亮 (n.d.) and Kuwakado Shidō 桑門至道 (n.d.) cautioned priests in subordinate temples that they must not forget to properly teach the sect's principle of the 'coexistence of ultimate and relative truth' (shinzoku nitai 真俗二諦), which at this time was widely interpreted as meaning that the Buddha's law (buppō 仏法) and the sovereign's law (óbo 王法) were harmonious and complementary. Ōtani and Kuwakado further advised that 'those in this sect in supervisory roles must pay special attention to what the priests and laity under their supervision are doing. ... You must eliminate misconceptions, being ever vigilant'. ${ }^{29}$ Only the most extreme of political radicals would have openly endorsed assassination of the emperor at this time, and in this sense, the religious leaders' denunciations are by no means surprising. At the same time, these comments not only denounced imperial assassination, but also implicated any political ideology critical of the existing social and economic order. The prevailing interpretation of the 'coexistence of ultimate and relative truth' is another example of how doctrine could be used to stifle social critique. In the wake of the Great Treason Incident-and the Buddhist response to it - it became increasingly difficult to critique the status quo of the socio-economic order from a Buddhist subject position.

At the national level, the incident intensified fears among political elites and the bourgeoisie over the rise of socialism, raising the spectre of revolt from organized labour and the urban underclass. But for

27 Sōtō shūhō, no. 340, February 15, 1911, translated and quoted in Victoria, Zen at War, 50.

28 Translated and quoted in Victoria, Zen at War, 50.

29 Chügai nippō, no. 3259, January 29, 1911, translated and quoted in Victoria, Zen at War, 51. 
Buddhists in particular, the fact that an outsized number of priests were implicated in the incident, whether directly or indirectly, was a particular cause for concern. Without citing the incident specifically, the Mutual Aid Society's founding charter reflected these anxieties:

...the structure of society grows increasingly complex, and the rapidly and violently changing economic situation causes the gap between rich and poor to grow ever more extreme and heightens the misery of the lower classes, who face difficulties in finding work and making ends meet. As a result, morals decay and evil runs rampant. But perhaps worst of all this has also led to dangerous and violent thought growing ever stronger, disrupting the customary social order and leaving a dark blot on enlightened culture. Reflecting on these corrupting influences is terrifying; the situation is truly deplorable. ${ }^{30}$

The Mutual Aid Society, like many philanthropic endeavours, represented diverse and sometimes competing interests held by various parties involved in its creation. For the Jōdoshū leadership, the project was a major piece in a larger campaign to honour the 700th anniversary of the death of Hōnen, the sect's founder. For Watanabe, it was an opportunity to implement his evolving ideas on social work as a form of religious and social practice that could address the problem of poverty in a more systematic and effective manner than traditional modes of charity.

While not directly involved in its creation, for bureaucrats, scholars, and benefactors connected to charity and relief work-whether through the Home Ministry or private organizations like the Central Charity Association-the project appeared to be an ideal example of the role that religious groups could and should play in addressing social problems and guiding the general public away from dangerous ideologies. In fact, even as the Jōdoshū Workers’ Mutual Aid Society was being launched, plans were under way for the Three Religions Conference (sankyō kaidō 三教会同), to be held in February 1912. ${ }^{31}$

\footnotetext{
30 'Jōdoshū rōdō kyōsai kai shuisho'.

31 This conference, organized by then vice-minister of home affairs Tokonami
} 
A major goal and theme of that conference, from the perspective of Home Ministry bureaucrats, was to promote religious groups' participation in activities that would strengthen national morality, improve society, and guard against 'dangerous thought'. ${ }^{32}$ As Sheldon Garon argues, however, the trend toward cooperative engagement between religious groups and government bureaucrats at this time was not a simple case of the government co-opting the religious; rather, it reflected a situation in which many influential religious leaders, whether Buddhist, Christian, or Shinto, sought greater social influence and discovered areas of common concern with government officials in which they were quite happy to pursue goals of shared interest. ${ }^{33}$ Although the Mutual Aid Society was not a direct product of this religious-bureaucratic cooperation, it embodied the hopes that the Home Ministry had for religious social work: shoring up the social order by addressing problems incrementally through private efforts that would, hopefully, forestall unrest and revolutionary politics.

Specific plans for Jōdoshū's commemorative social enterprise began taking more concrete form in September 1910 when the decision was made to target the working poor with a project to provide affordable accommodations as well as religious and moral guidance. As those preparations proceeded over the next several months, with land and buildings purchased, the project underwent a series of name changes prior to its official launch: Labour Protection Union (Rōdō hogo kumiai 労働保護組合); Jōdoshū Labour Protection Society (Jōdoshū rōdō hogo kai 浄土宗労働保護会); Tokyo Memorial

Takejirō 床波竹次郎 (1867-1935), built on the traditional notion of Buddhism, Shinto, and Confucianism as the 'three religions' of Japan. The new configuration replaced Confucianism with Christianity, which seemed much more socially potent despite its foreign origins. Tokonami sought to enlist clergy to support state efforts at implementing a 'spiritual restoration' that would foster national morality and contribute to social stability amid the disruptions produced by industrial capitalism. For a detailed study of this conference, see McKenzie, 'Spiritual Restoration and Religious Reinvention in Late Meiji Japan'.

32 Thelle, Buddhism and Christianity, 252.

33 Garon, Molding Japanese Minds, 17. 
Labour Protection Society (Tōkyō onki kinen rōdō hogo kai 東京遠 忌記念労働保護会); Workers' Mutual Aid Society (Rōdō kyōsaikai 労働共済会); and, finally, Jodoshū Workers' Mutual Aid Society. ${ }^{34}$ The change in names clearly suggests that there was a strong focus on labourers or workers from the project's inception. ${ }^{35}$

The society's focus on workers - and the use of the word 'labour' $\left(r_{\bar{d}} \overline{\mathrm{o}}\right)$ in its name-reflected changing trends in social and economic problems of the day as well as the responses to them. First, this focus acknowledged that able-bodied, working people were either struggling to find suitable work or not being paid enough to maintain their means of subsistence. Prior to industrialization, the only suitable or deserving recipients of poverty relief outside of natural disaster or famine victims were the sick, handicapped, widows, or small children-in other words, people incapable of work. Unequal access to education, legal or practical impediments to the organization of labour, and a lack of a public social safety net were three major causes of this situation. Second, by providing struggling or homeless workers with a variety of services, the Mutual Aid Society attempted to address the multiple and varied structural impediments that trapped so many urban residents in poverty. Watanabe's theory of social work, which he contrasted with prevailing modes of charity (jizen 慈 善) or relief (kyüsai 救済), emphasized the necessity of a preventative approach based on rational and coordinated poverty relief programs.

Prior to the launch of the Mutual Aid Society, Watanabe had not published any writings that dealt with social work in a comprehensive manner. His closest effort in this regard was a short article recommending a German-style program of childcare, published a few months after returning to Japan in July $1910 .{ }^{36}$ The first essay outlining his thoughts on how to improve the status quo for relief work was

\footnotetext{
34 Miyoshi, 'Jōdoshū rōdō kyōsai kai', 16-17.

35 Strictly speaking, the term for a 'worker' or 'labourer' is rōdōsha 労働者; however, I have translated rōdō労働 as either 'labour' or 'worker', depending on the context of the surrounding words. The point remains, however, that the term rōdo figured in each of the proposed names for the project.

36 This essay was published in July 1910. Watanabe, 'Kyōka no keiei'.
} 
'The essentials of charity work', which appeared in the pages of Shin bukkyō 新仏教 in December 1911. The next clearest statement of his approach to social work came with 'Five major principles of modern reformatory and relief work', which was published in the Mutual Aid Society's institutional organ, Rōdō kyōsai 労働共済, in January 1916, some five years after the society's launch. ${ }^{37}$ Although Watanabe frequently used the term 'social work' (shakai jigyo 社会事業) in writing, he did not use it in the title of a published piece of writing until 1918 in an essay titled 'Encouraging the rise of national social work'. ${ }^{38}$ This chronology of change in nomenclature from 'charity' to 'reformatory and relief work' to 'social work' generally coincides with the evolution of terminology in other venues, such as name changes made to the Central Charity Society and its publications. ${ }^{39}$

In light of this chronology, the society's founding charter and bylaws, which by all accounts Watanabe authored himself, offer insight into an early stage of the evolution of his thinking on social work and reveal how he envisioned the organization's role and function. ${ }^{40}$ The Mutual Aid Society charter reflected the common belief that rapid change transformed Japan and, while generally improving people's lives in the process, nevertheless presented new challenges. At this point in time, the Meiji government failed to produce legislation to adequately address the problems that arose as the result of society

\footnotetext{
37 Watanabe, 'Jizen jigyō no yōgi'; Watanabe, 'Gendai kanka kyūsai jigyō'.

38 This essay appeared in a 1918 issue of the Mutual Aid Society's journal, Rōdō kyōsai 労働共済. Watanabe, 'Kokuminteki shakai jigyō', 2-3.

39 The Central Charity Society (Chūō jizen kyōkai 中央慈善協会), founded
} in 1908, changed its name to the Central Social Work Society (Chūō jizen jigyō kyōkai 中央社会事業協会) in 1921. The society's journal, Charity (Jizen 慈善), which began publication in 1909, underwent a name change to Society and Relief (Shakai to kyūsai 社会と救済) in 1917 and then to Social Work (Shakai jigyō 社 会事業) in conjunction with the 1921 name change of the society itself. Tracing the evolution of institutional names can be a useful method of tracking conceptual changes-names tend not to change until a body of ideas has sufficiently taken root to make the change seem reasonable or even unavoidable.

40 'Jōdoshū rōdō kyōsai kai shuisho'. 
growing 'increasingly complex' while the 'rapidly and violently changing economic situation' caused the 'gap between rich and poor to grow ever more extreme'. Furthermore, workers faced 'difficulties in finding work and making ends meets', producing a situation in which 'morals decay and vice runs rampant'. ${ }^{41}$ A Buddhist's calling thus contained a moral component reminiscent of the one that Home Ministry bureaucrat Shiba Junrokurō 斯波淳六郎 (18611931) and others envisioned for clergy at the Home Ministry's inaugural Reformatory and Relief Work Seminar a few years prior. The charter statement differed, however, in that it depicted moral decay as a symptom of immiseration rather than its cause. Most disturbingly, the charter warned, the growing wealth gap and rate of poverty risked an outbreak of 'dangerous and violent thought', palpable expressions of which the Great Treason Incident had recently revealed.

Watanabe later argued in greater detail for the adoption of proactive poverty prevention, as opposed to a more passive strategy of poverty relief; and a concern for poverty clearly emerges in the charter. But the primary focus of the charter, likewise reflected in the society's name, related to the foundational, structural issue of labour (rōdo 労働) and the worker (rōdōsha 労働者) rather than the symptom of poverty itself. Indeed, the charter begins,

When considering the fate of our country's progress and the development of its culture, one must not overlook, even for an instant, investigation of the labour problem and implementation of relief work meant to address it. ${ }^{42}$

The charter identified 'labour protection' as Japan's 'greatest and most urgent task at present' and demanded that the government take a greater lead in addressing the 'labour problem'. While poverty was an important and closely related issue, the labour problem and the accompanying need for labour protection form the core object of the charter's call to action.

\footnotetext{
41 'Jōdoshū rōdō kyōsai kai shuisho'.

42 'Jōdoshū rōdō kyōsai kai shuisho'.
} 
Having identified the problem, the charter then outlines the proposed course of action for the Mutual Aid Society. Japan possessed an indigenous tradition of 'alms and relief work... from which contributions can be made to the task of addressing the labour problem'. ${ }^{43}$ Much of this tradition centred on ideals of compassion and benevolence found in religion, namely, Buddhism:

... surely it is the Buddha's teachings of compassion and salvation and the instruction to bring benefit and joy to living beings (riraku ujo 利楽有情) that perfectly demonstrated the obligation of all, whether high or low, to repay debts to the Buddha equally through interdependence (aiyori 相依り), reciprocity (gokei 互恵), and mutual aid (kyōsai 共済). ${ }^{44}$

For adherents of Jōdōshū, practice of these virtues was supposed to be a matter of daily conduct. All Buddhists, regardless of sectarian affiliation or social standing, bore a responsibility to perform acts of compassion that would address material needs. Whatever practical methods might be employed, they were to be rooted in Buddhist ethical ideals of interdependence, reciprocity, and mutual aid.

Finally, after noting the Mutual Aid Society's symbolic role in commemorating the 750th anniversary of Hōnen's death, the charter concludes by reiterating the society's commitment to 'strive first and foremost to improve the conditions of daily life for individual workers'. The group's other efforts would be directed at 'offering solace and encouragement and fostering a spirit of independence, self-respect, diligence, and perseverance', and, by doing so, 'also contribute to the improvement of workers' homes and family lives. ${ }^{45}$

The charter clearly expressed the view that the labour question posed the greatest urgency and that protections and material improvements for workers were therefore essential to attaining its stated goals of fighting poverty, ensuring social stability, and preventing

\footnotetext{
43 'Jōdoshū rōdō kyōsai kai shuisho'.

44 'Jōdoshū rōdō kyōsai kai shuisho'.

45 'Jōdoshū rōdō kyōsai kai shuisho'.
} 
the outbreak of political agitation for revolution. In terms of its aim to address poverty by examining structural causes, namely, the labour issue, the charter embodied principles of modern social work. Nevertheless, vestiges of the affective and emotional quality of traditional charity work remained, which Watanabe later highlighted and criticized more directly in his writings. These vestiges attest to the Mutual Aid Society's belonging to a historical period in which patterns of providing aid to the poor, whether relief work, scientific charity, or social work, were all evolving in terms of principles and practices. For example, the 'solace' (ian 慰安) mentioned in the charter's closing paragraph echoes the 'spiritual solace' (seishin jō no ian 精神上の慰安) discussed at the 1908 Reformatory and Relief Work Seminar. A focus on spiritual solace, in itself, does not necessarily deviate from the general trajectory of Watanabe's conception of Buddhist social work. But to the extent that it suggests religious faith be deployed as a palliative for the emotional—but not physical—distress caused by poverty (as Shiba's notion did), it undermines the call for Buddhists to make the alleviation of suffering-both spiritual and material - part of daily religious practice.

Another example of traditional attitudes toward poverty figure in the charter's stated aim of improving the home or family life of the working class. This goal is redolent of the 'friendly visiting' strategy at the heart of the Charity Organization Society's (COS) model of relief work in late-nineteenth century Britain and the United States. The COS model sought to eliminate indiscriminate dispersal of aid in cash from public funds (so-called 'outdoor relief', as opposed to the 'indoor relief' of the poor house) and replace it with a system of 'scientific charity' directed by 'friendly visitors', middle-class volunteers who assessed the moral, emotional, and physical causes of poverty of each household on a case-by-case basis. The system was imbued with bourgeois paternalism and a confident belief that moral guidance could successfully set the 'deserving poor' on a path toward independence and self-sufficiency through work. ${ }^{46}$ The COS and its method of 'friendly visiting' presume a great deal about the connec-

\footnotetext{
46 For an overview of the origin and history of the COS in Britain, see Hum-
} 
tion between morality and poverty, ideas at odds with Watanabe's rejection of pretences of social hierarchies and moral superiority in later writings. This is not to suggest a fundamental disharmony in Watanabe's conception of Buddhist social work for the Mutual Aid Society or other endeavours. Rather, it is to emphasize that Watanabe's turn toward the modern and scientific methods of social work did not manifest as a sharp break with existing practices but evolved in a gradual and sometimes dialectical fashion.

The Mutual Aid Society's charter outlined the social context, religious motivations, and ideological concerns of its founders. Meanwhile, its by-laws described a fairly standard organizational structure. Item 3 in the charter, however, clarified that in order 'to improve the living conditions of labourers and promote a spirit of advancement', the society would administer projects in the following seven areas: lodging house for labourers, provision of food at cost, child care, job introduction services, recreation and instruction, assistance in applying for disability aid, and housing reform. ${ }^{47}$

The group's first successful project was its lodging house. In this endeavour they followed in the path of earlier Buddhist efforts, such as the free lodging house established by Ōtani-ha cleric Ōkusa Ejitsu 大草慧実 (1858-1912) while he served as head priest at Asakusa Hongan-ji in Tokyo. In subtle ways, however, the Mutual Aid Society reflected changes rooted in Watanabe's theoretical distinction between existing modes of traditional charity and those of modern social work. If there was a central concept or guiding philosophy contained in the original charter, it was the Buddhist principle of interdependence. Characterizing the organization as a 'mutual aid' society among workers distinguished it from associations created to 'protect' or 'care for' workers, as the earlier proposed name rōdo hogokai would have suggested. Related to this example is the distinction between the gratis nature of the free lodging house run by the priest Ōkusa and Asakusa Honganji, on the one hand, and the low-cost or

phreys, Poor Relief. For a case study examining the effectiveness of the COS model in the United States, see Ziliak, 'Self-Reliance before the Welfare State'.

47 'Jōdoshū rōdō kyōsaikai shuisho'. 
at-cost nature of the Mutual Aid Society, on the other. Making the facilities not free, but very affordable, was a purposeful feature meant to embody the spirit of mutual aid and chip away at the conventional master-dependent relationship that commonly existed between the philanthropist or donor and the recipient of aid.

\section{Buddhism and the labour question in Watanabe Kaigyoku's thought}

How exactly did Watanabe envision the nature of the labour problem from a Buddhist perspective? His thoughts on this topic emerged more clearly in a 1919 essay titled 'A Buddhist View of the Labour Question'. In this essay, Watanabe identified the labour problem as the central political and economic concern for post-World War One Japan, as well as for the victorious powers of Britain, France, and the United States. He noted three aspects in particular: the international nature of the 'labour problem'; the propensity for the proletariat to subsume all other classes and present itself as the most important; and the tremendous political nature of the problem. ${ }^{48}$ In considering the labour problem from a Buddhist perspective, Watanabe divided his analysis into two areas: the theoretical, in which he considered the place of labour within Buddhism and attempted to develop a Buddhist critique of the labour problem; and the practical-how a Buddhist should try to deal with the problem and whether Buddhists could be effective in resolving the labour problem in real life. ${ }^{49}$

Watanabe first pointed out that, theoretically speaking, 'religion and labour did not contradict each other'. ${ }^{50}$ Rather, having only just left the 'slave stage' of human development and entered into

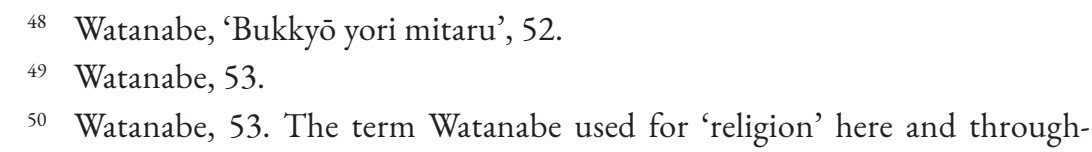
out the essay is shükyo 宗教. By the 1910s, shükyo had become widely adopted in Japan as the standard translation word for the English term 'religion' and its cognates in French, German, and other European languages. Nevertheless, other terms still remained in circulation, though less commonly used. This diversity of 
the 'material stage', there was an overwhelming focus on the material-improving workers' standards of living, securing livelihoods, and the struggle of the 'miserable' class. Although this was the current reality, he argued the present stage should nevertheless be understood in light of the spiritual stage, which was yet to come. Watanabe acknowledged that the present social and economic structure was based upon class difference, and thus class conflict would continue unabated under the current structure. ${ }^{51}$ In his view, the widespread anti-religious sentiment in the labour movement could be attributed to the atheism and social Darwinism that inhered in the materialist view of history and contemporary Marxian thought. He also argued that the flames of popular antipathy toward religion in Europe were fanned by powerful families with close ties to state-sponsored churches who used their influence to align religion with the political interests of the wealthy. ${ }^{52}$ 'Supporters of the labour movement', he observed, 'are intent on thinking of new things and reforms, thus it is no surprise that they clash with religion, which only seeks to maintain old forms and structures. But there is no reason why the labour problem must necessarily be solved only according to Marxist theories or based upon atheism'. ${ }^{53}$ Watanabe cited the examples of Pope Leo XIII's (1810-1903) formation of a Catholic labour alliance and social policy; Bismarck's state social policy in Germany; and Friedrich Naumann (1860-1919), leader of a Christian-socialist movement in Germany. Watanabe argued that these examples proved the existence and potential effectiveness of non-Marxist, non-materialist, non-atheist, religiously grounded methods of dealing with the labour problem.

In order to explore these potential religiously informed solutions, Watanabe outlined the bases from which to best approach the labour problem in terms of Buddhist doctrine. First, Watanabe questioned the validity of taking an exclusively materialist or Marxist approach

terminology reflected not only personal literary style but also continued contestation of what constituted 'religion'.

51 Watanabe, 53.

52 Watanabe, 54.

53 Watanabe, 55. 
to history and argued instead that one should identify the history of humanity with the pursuit of ideals. He claimed that religion was 'the basis and ideal for human cultural activity as a whole' and suggested that 'if we rephrase the idea that the meaning of human history lies in the pursuit of ideals in Buddhist terms, we might say the history of human kind is the "quest for enlightenment" (jog $u$ bòdai 上求菩提) and the process of proceeding toward the eternal and infinite heights'. ${ }^{54}$ Acknowledging the economic aspect of human history and life activity, Watanabe emphasized that although human beings made 'things', humans themselves were not simply 'things'. Moreover, while human labour may produce 'things', this was by no means the only end towards which human labour may be directed. Ultimately, he concluded that a materialist worldview lacked a solid foundation for justice, humanitarianism, or freedom: 'It is not fluid in action and lacks balance and harmony'. ${ }^{55}$

Another flaw he located in social Darwinist and materialist thought was an insistence on conflict without regard to what sort of peace or harmony might be achieved beyond the cessation of conflict. 'War', he wrote, 'is not a goal in itself, but rather a means'. If conflict was to occur at all, it should serve only as a means to achieving peace. Looking at the proletarian-centred labour movement of his day, Watanabe expressed concern that it would simply lead to proletarian tyranny, intent on pursuing the interests of one class while violently subjugating all others. In his estimation, such a view overlooked the fact that human culture developed according to the full expression of the division of labour and cooperative coexistence among these divisions. ${ }^{56} \mathrm{~A}$ spirit of cooperation and a commitment to giving full play to all forms of human and social ability must therefore figure centrally in any attempt to solve the labour question. In Buddhist terms, in relation to the aforementioned 'quest for enlightenment', this approach can be summed up in the concept of 'saving those below' (geke shujō 下化衆生). The 'quest for enlightenment' characterized

\footnotetext{
54 Watanabe, 'Bukkyō yori mitaru', 56.

55 Watanabe, 56.

56 Watanabe, 56-57.
} 
the pursuit and realization of the ideal. Within the conception of the ideal was both 'limitless light' (mugen no kōmyō 無限の光明) and 'eternal life' (eien no seimei 永遠の生命). 'Limitless light', Watanabe explained, 'refers to human wisdom and spiritual ability... eternal life refers to the state of human safety and happiness'. ${ }^{57}$ For Watanabe, resolution of the labour problem began with this ideal. 'Saving those below', that is, the altruistic work of the bodhisattva to save others, corresponded to political goals of coexistence and world peace. A comprehensive solution to the social, national, and international aspects of the labour problem could only be achieved through a commitment to both approaches.

In addition to the central principles of 'seek enlightenment above, save those below', Watanabe drew attention to the Buddhist teachings of inclusivity, no-self, and non-attachment, all of which recognized an existence greater than the self. Important, too, was the concept of 'repayment of obligation' (bōon 報恩). He extended this latter notion into the economic realm by identifying it with the practice of mutual assistance and related it in political or social terms to the spirit of coexistence. ${ }^{58}$ The deeper significance of both mutual assistance and coexistence, he argued, could be found in the 'repayment of obligation'. A third concept he introduced was the act of 'rejoicing in the good deeds of others' (zuiki 随喜). Watanabe emphasized that this Buddhist concept allowed for appreciation of good works done by non-Buddhists, in contrast with a western Christianity that, in his view, generally refused to acknowledge the truth or goodness found in other religions. He also briefly touched on the concepts of 'sharing of one's own karmic merit with others' (ekō 迴向) and 'repentance for one's negative actions' (sange 懺悔), which together formed a basis for realizing a true solidarity among people from all nationalities and social classes. Ultimately, Watanabe argued for the creation of a new cooperative spirit among people based upon the teaching of 'saving those below' as a means of resolving contemporary class conflict, while also calling for a new idealism in the cultural realm based upon the teaching of

57 Watanabe, 'Bukkyō yori mitaru', 57.

58 Watanabe, 57. 
'seeking enlightenment above' as a means for overcoming a purely materialist view of human history. ${ }^{59}$ In discussing these Buddhist concepts in light of contemporary social conditions, Watanabe only sketches in outline form how they might be applied practically. Nevertheless, this endeavour to use Buddhist teachings in dialogue with present circumstances and apply them practically is recognizable as an integral part of what we now describe as engaged Buddhism.

Watanabe also appealed specifically to the Pure Land practice of the nenbutsu 念佛, as developed by Jōdoshū sect founder Hōnen 法 然 (1133-1212). Hōnen's teaching, he claimed, actually ran 'contrary to a national policy that envisions the entire nation of Japan as the "children" of the emperor'. Rather, in establishing the Pure Land teaching, Hōnen sought to 'enlighten the empress above and the prostitute below' ${ }^{60}$ He thus concluded, 'Based on this same ethos, today we, too, must do away with capitalist Buddhism and take a position rooted in a Buddhism of equality'. ${ }^{61}$

This brief exploration of Watanabe's thought should make clear that even though he sympathized with certain socialist or anti-establishment political viewpoints, one can hardly characterize him as challenging the authority of the state or pursuing a politics that relativized the national in favour of the international. That being said, the ideas Watanabe expounded in 'A Buddhist view of the labour question' and other writings are suggestive of what I would term a Buddhist cosmopolitanism. He remained firmly enmeshed in a view of the world ordered by ethnic identities and membership to nation-states, but he nevertheless imagined a future in which Buddhism would facilitate a global convergence of human culture. While Watanabe did not challenge state authority, he did attempt to stand

59 Watanabe, 'Bukkyō yori mitaru', 58.

60 Watanabe's original phrasing for these two somewhat provocative statements are as follows: 'Nihon no banmin kotogotoku heika no akago de aru to iu kokuze ni han suru’ 日本の万民悉く陛下の赤子であるという国是に反する; and 'Hōnen shōnin wa jōdomon o hiraite ue wa kōgō o kyōka shi shita wa yūjo o mo kyōka shita’ 法然上人は浄土門を開いて上は皇后を教化し下は遊女をも教化した.

61 Watanabe, 'Bukkyō yori mitaru', 59. 
apart from it as a Buddhist - at least rhetorically-in the way he presented Buddhist social ethics as a necessary supplement to problems that neither the state nor oppositional political movements, like organized labour or socialism, could adequately address on their own. This may be a fine-grained distinction, but I would argue that in this sense Watanabe was a prototypical example of an engaged Buddhist. $\mathrm{He}$ articulated a vision and pursued practical action for social reform rooted in Buddhist doctrine that, while perhaps not revolutionary, sought to ameliorate the status quo by reforming and humanizing economic and social conditions under industrial capitalism.

There is no denying that Watanabe Kaigyoku's conceptualization of the role that religion-specifically, Mahayana Buddhism- played in social reform and progress was idealist, or perhaps even utopian. It might be easy to write him off as a hopeless Buddhist romantic or a pie-in-the-sky academic cleric, were it not for his programmatic dedication to education and social work. When compared to his actual accomplishments, close scrutiny of the social vision depicted in his written work suggests Watanabe's imaginative reach exceeded his practical grasp. Nevertheless, he stands out as a figure who succeeded in putting into practice real, tangible examples of his own vision for Buddhist-inspired social reform.

\section{Bibliography}

\section{Primary sources}

Jōdo kyōhōo浄土教報 [Jōdoshū periodical]. Tokyo: Jōdo kyōhosha 浄 土教報社, 1889-1944.

Jōdoshū rōdō kyōsai 浄土宗労働共済会. 'Jōdoshū rōdō kyōsai kai shuisho’ 浄土宗労働共済会趣意書 [Charter Statement for the Jōdoshū Workers' Mutual Aid Society]. Jōdo kyōhō 浄土教報 [Periodical of Jōdo Buddhism] 3 April, no. 949 (1911): 6-7.

Kogetsu zenshū kankō kai 壶月全集刊行会, ed. Kogetsu zenshū 茞

月全集 [Collected Works of Watanabe Kaigyoku]. Vols. 1-2.

Tokyo: Daitō Shuppansha 大東出版社, 1977.

'Rōdō to hōshi no aida: shūmon mo ningensei yutaka na shokuba ni' 
労働と奉仕の間:宗門も人間性豊かな職場に [Between labour and service: Buddhist sects should also strive to create more humane workplaces]. Chūgai Nippōo 中外日報 [Chugai Daily], May 17, 2017. Editorial.

Watanabe Kaigyoku 渡辺海旭. 'Bukkyō yori mitaru rōdō mondai' 仏教より見たる労働問題 [A Buddhist View of the Labour Question].Jōdo kyōhōo 浄土教報 [Periodical of Jōdō Buddhism] 21 (November 1919). Reprinted in Kogetsu zenshū 壹月全集 [Collected Works of Watanabe Kaigyoku]. Vol. 2, 52-59. Tokyo: Daitō Shuppansha 大東出版社, 1977.

———. 'Daijō Bukkyō no seishin'大乗仏教の精神 [The Spirit of Mahayana Buddhism]. In Zōjō-ji nichiyō kōenshū 増上寺日曜講 演集 [Collection of Sunday Lectures at Zōjō-ji], edited by Zōjōji kyōhōka 増上寺法教課. Tokyo: Jōdo kyōhōsha 浄土教報社, January 1921. Reprinted in Kogetsu zenshü 壼月全集 [Collected Works of Watanabe Kaigyoku]. Vol. 2, 79-95. Tokyo: Daitō Shuppansha 大東出版社, 1977.

———. 'Gendai kanka kyūsai jigyō no go daihōshin' 現代感化救済事 業の五大方針 [Five major principles of modern reformatory and relief work]. Rōdō kyōsai 労働共済 2, no. 2 (1916). Reprinted in Kogetsu zenshū 壼月全集 [Collected Works of Watanabe Kaigyoku]. Vol. 2, 17-22. Tokyo: Daitō Shuppansha 大東出版社, 1977.

——_. 'Jizen jigyō no yōgi' 慈善事業の要義 [The Essentials of Charity Work]. Shin bukkyo 新仏教 12, no. 12 (1911). Reprinted in Watanabe Kaigyoku kenkyü: sono shisō to kōdō 渡辺海旭研究 : その思想と行動 [A Study of Watanabe Kaigyoku: His Thought and Activities], by Serikawa Hiromichi, 218-20. Tokyo: Daitō Shuppansha 大東出版社, 1978.

- - . 'Kochū kenkon' 壼中乾坤. Shin bukkyō新仏教 8, nos. 1-5 (1907). Reprinted in Kogetsu zensh $\bar{u}$ 瑴月全集 [Collected Works of Watanabe Kaigyoku]. Vol. 2, 431-49. Tokyo: Daitō Shuppansha 大東出版社, 1977.

- — . 'Kokuminteki shakai jigyō no bokkō o unagasu' 国民的社会 事業の勃興を促す [Encouraging the rise of national social work]. Rōdō kyōsai 労働共済 [Mutual Aid Society's journal] 4, no. 3 (1918): 2-3.

———. 'Kyōka no keiei subeki kōki jizen jigyō no hitotsu' 教家の 
経営すべき夏期慈善事業の一 [A summer-season charity project that (Buddhist) instructors should administer]. Shükyōkai 宗教 界 [Religious World] 5.7 (July 1910).

- - - 'Nissōkan rō zakkan’ 日想観楼雑感, Jōdo kyōhō, no. 433 (May 1901). Reprinted in Kogetsu zenshū 壸月全集 [Collected Works of Watanabe Kaigyoku]. Vol. 2, 411-15. Tokyo: Daitō Shuppansha 大東出版社, 1977.

\section{Secondary sources}

Garon, Sheldon. Molding Japanese Minds: The State in Everyday Life. Princeton: Princeton University Press, 1997.

Gavin, Masako, and Ben Middleton, eds. Japan and the High Treason Incident. London: Routledge, 2013.

Humphreys, Robert. Poor Relief and Charity, 1869-1945: The London Charity Organisation Society. New York: Palgrave, 2001. Ives, Christopher. Imperial-Way Zen: Ichikawa Hakugen's Critique and Lingering Questions for Buddhist Ethics. Honolulu: University of Hawai'i Press, 2009.

Kikuchi Masaharu 菊池正治, and Murota Yasuo 室田保夫, eds. Nihon shakai fukushi no rekishi 日本社会福祉の歴史 [A History of Japanese Social Welfare]. Kyoto: Mineruva Shobō ミネルヴァ書 房, 2003.

Kikuchi Yui 菊池結. 'Watanabe Kaigyoku to sono keifu’ 渡辺海旭と その系譜 [Watanabe Kaigyoku and His Lineage]. In Jōdoshū no oshie to fukushi jissen 浄土宗の教えと福祉実践 [Jōdoshū teachings and welfare practice], edited by Jōdoshū Sōgō Kenkyūjo 浄土宗 総合研究所, 171-86. Tokyo: Nonburusha ハンブル社, 2012.

McKenzie, Timothy S. 'Spiritual Restoration and Religious Reinvention in Late Meiji Japan'. Ph.D. dissertation, The Lutheran School of Theology at Chicago, 2003.

Miyakawa Sachiko 宮川佐知子. 'Shinshū Ōtani-ha: zangyōdai miharai “shikyū sezu” oboegaki sō futari, tsuki 130-jikan mo' 真 宗大谷派:残業未払い「支給せず」覚書 僧 2 人、月 130 時間も [Shinshū Ōtani-ha: memorandum on unpaid overtime for two monks, as many as 130 hours a month]. Mainichi shinbun 毎日 新聞 [Tokyo evening edition], April 26, 2017: 8. 
Miyoshi Issei 三好一成. 'Jōdoshū rōdō kyōsai kai no setsuritsu to jigyō no tenkai' 浄土宗労働共済会の設立と事業の展開 [The Establishment of the Jōdoshū Workers' Mutual Aid Society and the Development of its Activities]. Hasegawa bukkyō bunka kenkyüjo nenpō 長谷川仏教文化研究所年報 [Bulletin of Hasegawa Research Institute of Buddhist Culture] 24 (1999): 1-53.

Nihon bukkyō shakai fukushi gakkai 日本仏教社会福祉学会. Bukkyō shakai fukushi jiten 仏教社会福祉辞典 [A Dictionary of Buddhist Social Welfare]. Kyoto: Hōzōkan 法藏館, 2006. Rambelli, Fabio. Zen Anarchism: The Egalitarian Dharma of Uchiyama Gudō. Berkeley: Institute of Buddhist Studies and BDK America, Inc., 2013.

Serikawa Hiromichi 芹川博通. Bukkyō to fukushi: kyōsai shugi to kyōsei shugi 仏教と福祉: 共済主義と共生主義 [Buddhism and Welfare: Mutual Aid and Coexistence]. Tokyo: Hokuju Shuppan 北樹出版, 2008.

- - - Watanabe Kaigyoku kenkyū: sono shisō to kōdo 渡辺海旭研究: その思想と行動 [A Study of Watanabe Kaigyoku: His Thought and Activities]. Tokyo: Daitō Shuppansha 大東出版社, 1978.

Swanson, Paul L. 'Takagi Kenmyō and Buddhist Socialism: A Meiji Misfit and Martyr'. In Modern Buddhism in Japan, edited by Hayashi Makoto, Ōtani Eiichi, and Paul L. Swanson, 144-63. Nagoya: Nanzan Institute for Religion and Culture, 2014. Thelle, Notto R. Buddhism and Christianity in Japan: From Conflict to Dialogue, 1854-1899. Honolulu: University of Hawai'i Press, 1987.

Thomas, Jolyon Baraka. Faking Liberties: Religious Freedom in American-Occupied Japan. Chicago: University of Chicago Press, 2019.

Victoria, Brian Daizen. Zen at War. New York: Weatherhill, 1997. Yoshida Kyuichi 吉田久一. Nihon kindai bukkyō shakaishi kenkyū (ge) 日本近代仏教社会史研究(下) [Studies in the Social History of Modern Japanese Buddhism, vol. 2]. Tokyo: Kawashima Shoten 川島書店, 1991.

Ziliak, Stephen T. 'Self-Reliance before the Welfare State: Evidence from the Charity Organization Movement in the United States'. The Journal of Economic History 64, no. 2 (2004): 433-61. 